\title{
Mesozoic lithospheric rejuvenation of South China: Evidence from magmatic zircon $\mathrm{Hf}-\mathrm{O}$ isotopes
}

\author{
JIN-HUI YANG ${ }^{12 *}$, JI-HENG ZHANG ${ }^{12}$, JING-YUAN
} CHEN $^{13}$, JIN-FENG SUN ${ }^{12}$

${ }^{1}$ State Key Laboratory of Lithospheric Evolution, Institute of Geology and Geophysics, Chinese Academy of Sciences, Beijing 100029, China.

${ }^{2}$ University of Chinese Academy of Sciences, Beijing 100049, China

${ }^{3}$ School of Earth Science and Resources, Chang'an University, Xi' an 710054, China

*Corresponding author: Yang JH, jinhui@mail.igcas.ac.cn

Contients generally contrain ancient nuclei thaat enclosed by younger tectonic domains, and are commonly rejuenized by later tectonic, magmatic and metamorphic processes. Whole geochemsitry and zircon U-Pb and Hf-O isotopes of Early Jurassic gabbro, syenites and A-type granites are presented to constrain the sources and petrogenesis of these rocks, and to further trace the rejuvenation processes of continental crust in South China.

Early Jurassic gabbros have low $\mathrm{SiO}_{2}$ and high $\mathrm{MgO}$, $\mathrm{TiO}_{2}, \mathrm{Cr}$ and $\mathrm{Ni}$ concentrations, with weak negative $\mathrm{Nb}$ and Ta anomalies, variable whole rock initial ${ }^{87} \mathrm{Sr} /{ }^{86} \mathrm{Sr}$ ratios (0.7064-0.7117), $\varepsilon_{\mathrm{Nd}}(\mathrm{t})(-1.5$ to +0.6$), \varepsilon_{\mathrm{Hf}}(\mathrm{t})(-1.6$ to +5.7$)$ and zircon $\varepsilon \mathrm{Hf}(\mathrm{t})$ values $(+3.4$ to +6.4$)$ and mantle-like $\delta^{18} \mathrm{O}$ values $(+4.9$ to $+6.2 \%)$. They are inferred to be derived from partial melting of a fertile lithospheric mantle source, with subsequent crustal assimilation and fractional crystallization. The Early Jurassic syenites are high-K calc-alkaline to shoshonitic rocks with high $\mathrm{La} / \mathrm{Yb}_{\mathrm{CN}}$ rations, strongly negative $\mathrm{Sr}, \mathrm{P}$ and $\mathrm{Ti}$ anomalies, low initial ${ }^{87} \mathrm{Sr} /{ }^{86} \mathrm{Sr}$ ratios, and high $\varepsilon_{\mathrm{Nd}}(\mathrm{t})$ (up to +5.3 ) and $\varepsilon_{\mathrm{Hf}}(\mathrm{t})$ (up to +11.5 ) values, indicating that they were generated by low-percentage partial melting of an amphibole-bearing lithospheric mantle in the garnet stability fields, with subsequent crustal assimilation and extensively crystal fractionation and/or cumulate. Whereas, the geochemical features show that the Early Jurassic K-feldspar granites were mainly generated by extensive crustal assimilation of alkaline (syenitic) magmas after crystal fractionation.

The Early Jurassic magmatism was possibly related to delamination of the flat-subducted Paleo-Pacific plate beneath South China that induced asthenospheric upwelling and provided heat to partial melting of above lithospheric mantle. The underplating of depleted mantle-derived magmas modified the structures and components of continental crust, indicating lithospheric rejuvenation during Early Jurassic in South China. 